\title{
Choroby asociované s imunoglobulinem IgG4 - editorial
}

\author{
Jan Krejsek \\ Ústav klinické imunologie a alergologie LF UK a FN Hradec Králové
}

\begin{abstract}
Komentář k | Editorial on
Adam Z et al. Remise "the disease associated/related with immunoglobulin IgG4" provázeného mnohočetnou lymfadenopatií po léčbě rituximabem a dexametazonem: kazuistika. Vnitř Lék 2017; 63(3): 290-299.
\end{abstract}

Autoři Adam et al podali lékařské veřejnosti ve své práci „Remise onemocnění asociovaného s imunoglobulinem lgG4 (IgG4 releated disease) provázeného mnohočetnou lymfadenopatií po léčbě rituximabem a dexametazonem" kvalitní informaci, jak diagnostikovat, a především jak účinně léčebně ovlivnit tuto nemoc. V českém odborném písemnictví tím dobře navazují na předchozí práce věnující se tomuto relativně vzácnému onemocnění, které dokládají, že v této oblasti nezaostáváme za rozvinutým světem. Sdělení podněcuje k úvahám ukazujícím na naše současné limity chápání patogeneze některých onemocnění, jejich diagnostiky a na možnosti léčebného ovlivnění.

Zánětlivá onemocnění asociovaná se zvýšenou hladinou protilátek podtřídy lgG4 mohou postihnout prakticky každý orgán $v$ našem těle. Je na ně třeba myslet v diagnostických rozvahách a využít možností histopatologického průkazu plazmatických buněk obsahujících IgG4 v bioptickém vzorku postižené tkáně jako objektivního kritéria. Zvýšenou hladinu protilátek lgG4 v séru Ize považovat za biomarker s vysokou senzitivitou, ale s nízkou specifitou. Připomínám, že nárůst protilátek podtrí́dy lgG4 specifických pro alergen je důkazem účinnosti imunoterapie alergenem. Vysoké hladiny těchto protilátek mají např. včelaři jako důsledek opakovaného včelího bodnutí. Protilátky podtřídy lgG4 mají v porovnání s dalšími třídami a podtřídami imunoglobulinů unikátní imunobiologické charakteristiky. Na jejich základě můžeme uvažovat o možnosti, že tvorba těchto protilátek je pouze epifenomén provázející danou formu poškozujícího zánětu. $V$ jiných situacích je můžeme považovat za integrální součást poškozujícího zánětu. Jejich př́tomnost je však možné interpretovat i jako snahu těla o regulaci poškozujícího zánětu. Bohužel, u člověka je obtížné hledat experimentální důkazy o těchto možnostech. $Z$ objektivních důvodů je v této situaci velmi obtížné dělat závěry ze zvířecích modelů.

Je dobré, že na toto onemocnění lékaři různých klinických oborů pamatují. Je to možné doložit i z bohaté literatury v českých pramenech. Po stanovení diagnózy onemocnění asociovaného s imunoglobulinem lgG4 je třeba tuto skutečnost zapojit do komplexních úvah o léčebné strategii optimální pro daného pacienta. Velmi účinné jsou v tomto ohledu kortikosteroidy. Bohužel, vedle všech běžných obtíží spojených s aplikací kortikoidů je největším problémem skutečnost, že při jejich použití dochází k relapsu onemocnění. Hledají se tedy způsoby, jak účinněji, a především dlouhodobě pozitivně ovlivnit zdravotní stav těchto nemocných. Brněnští autoři úspěšně použili biologikum, které cílí na molekulu CD20, rituximab. Rituximab můžeme právem považovat za jedno z nejpoužívanějších biologik. Jeho původní indikací při schválení v roce 1997 byla léčba lymfoproliferativních onemocnění vycházejících z B-lymfocytární větve. Účinnost je postupně prokázána i u dalších onemocnění, v jejichž patogenezi se uplatňuje B-lymfocytární systém. Jedná se především o imunopatologická onemocnění spojená s tvorbou autoprotilátek, např. systémový lupus, kožní onemocnění, např. pemphigus, dále trombotická trombocytopenická purpura, myasthenia gravis a další. Terapie antiCD20 je aplikována u pacientů, kteří nereagují dostatečně na standardní léčbu nebo u nich dochází k relapsu onemocnění. Účinek biologik antiCD20 v těchto stavech nemůžeme vysvětlit pouze jako depleci zralých B-lymfocytů exprimujících membránovou molekulu CD20 mechanizmy na protilátce závislé cytotoxicity, aktivací komplementového systému nebo indukcí apoptózy. Pozitivně bude nepochybně působit také ovlivnění imunobiologických aktivit B-lymfocytů spočívajících v podpoře T-lymfocytární odpovědi, a to bud've formě antigen prezentujících buněk, nebo ve formě cytokinové podpory T-lymfocytů. Takto bychom si alespoň z části mohli vysvětlit překvapivé výsledky klinických studií, které prokázaly účinnost biologické terapie antiCD20 humanizovanou monoklonální protilátkou okrelizumabem u nemocných s roztroušenou sklerózou mozkomíšní. Tu Ize stručně definovat jako zánětlivé neurodegenerativní onemocnění postihující CNS. Roztroušená skleróza patří k nejlépe prozkoumaným imunopatologickým onemocněním člověka. V našem chápání 
její patogeneze až donedávna jasně převládalo, že poškozující zánět je zprostředkován Th1 a Th17 T-lymfocyty. Pro účast B-lymfocytárního systému v tomto onemocnění $v$ našich úvahách nebylo významnější místo $s$ výjimkou skutečnosti, že u nemocných $s$ roztroušenou sklerózou prokazujeme $v$ jejich likvoru oligoklonální imunoglobuliny, které jsou tvořeny intratékálně. Pro tyto imunoglobuliny nebyl nalezen přímý podíl na poškozujícím zánětu. Nově však bylo prokázáno, že u nemocných $\mathrm{s}$ roztroušenou sklerózou, podobně jako u jiných onemocnění charakterizovaných účastí poškozujícího zánětu, Ize prokázat organizované lymfatické struktury, tzv. terciární lymfatické tkáně prímo v CNS. Tyto a jiné skutečnosti vedly ke klinickým pokusům, které zřetelně prokázaly, že biologikum antiCD20 okrelizumab je účinné v léčbě remitující/relabující formy i primárně progresivní formy roztroušené sklerózy. Tím se podstatně rozšírily možnosti, jak léčebně ovlivnit průběh onemocnění roztroušenou sklerózou mozkomíšní. Biologikum antiCD20 lze právem pokládat za, do velké míry panaceum, v léčbě onemocnění v jejich patogenezi se uplatňuje poškozující zánět.

Výše uvedené okolnosti dokládají, že nesmíme ustrnout v stávajícím chápání fungování lidského těla ve zdraví i nemoci. Jsme-li připraveni, mohou se nám otevř́t zcela nové obzory. Je to jistě pro prospěch obecného poznání fungování živého. Je to však prospěšné především pro naše pacienty. $V$ některých ohledech nám tyto nové poznatky naznačují i cesty, jak nemocem předcházet. Významnou úlohu v tom sehrává naše chápání fungování imunitního systému jako součásti obranného i poškozujícího zánětu. Fungování imunitního systému můžeme všichni pozitivně ovlivnit svým životním stylem, především stravováním, podporou střevní mikrobioty a pohybovou aktivitou.

\section{Literatura}

1. Abraham M, Khosroshahi A. Diagnostic and treatment workup for IgG4-related disease. Expert Rev Clin Immunol 2017; 13(9): 867-875. Dostupné z DOI: <http://dx.doi.org/10.1080/1744666X.2017.1354698>.

2. Frampton JE. Ocrelizumab: First global approval. Drugs 2017; 77(9): 1035-1041. Dostupné z DOI: <http://dx.doi.org/10.1007/ s40265-017-0757-6>

3. Kawa $S$, Skold M, Ramsden DB et al. Serum IgG4 concentration in IgG4-related disease. Clin Lab 2017; 63(9): 1323-1337. Dostupné z DOI: <http://dx.doi.org/10.7754/Clin.Lab.2017.170403>.

4. Trampert DC, Hubers LM, van de Graaf SFJ et al. On the role of IgG4 in inflammatory conditions: lessons for lgG4-related disease. Biochim Biophys Acta 2017. pii: S0925-4439(17)30273-9. Dostupné z DOI: <http://dx.doi.org/10.1016/j.bbadis.2017.07.038>.

5. Yadlapati S, Verheyen E, Efthimiou P. IgG4-related disease: a complex under-diagnosed clinical entity. Rheumatol Int 2018; 38(2): 169 177. Dostupné z DOI: <http://dx.doi.org/10.1007/s00296-017-3765-7>.

6. Krejsek J, Andrýs C, Krčmová I. Imunologie člověka. Garamon: Hradec Králové 2016. ISBN 978-80-86472-74-4.

\section{prof. RNDr. Jan Krejsek, CSc.}

هjan.krejsek@fnhk.cz

Ústav klinické imunologie a alergologie LF UK a FN Hradec Králové

www.fnhk.cz

Doručeno do redakce 11. 9. 2017 